CUBA AND THE UNITED STATES 
THIS PAGE INTENTIONALLY LEFT BLANK 


\section{CUBA AND THE UNITED STATES Intervention and Militarism, 1868-1933}

José M. Hernández

$\rightarrow$ University of Texas Press, Austin 
Copyright $(\odot \mathrm{I} 993$ by the University of Texas Press

All rights reserved

Printed in the United States of America

First edition, 1993

Requests for permission to reproduce material from this work should be sent to Permissions, University of Texas Press, Box 7819 , Austin, TX 78713-7819.

\section{Library of Congress Cataloging-in-Publication Data}

Hernández, José $M$.

Cuba and the United States : intervention and militarism, 1868-1933 / José M. Hernández. - Ist ed.

p. $\mathrm{cm}$.

Includes bibliographical references and index. ISBN 978-0-292-72375-7

r. United States-Foreign relations-Cuba. 2. CubaForeign relations-United States. I. Title.

EI83.8.C9H47 I 993

$327.730729 \mathrm{I}$-dc20

92-2 1 342

ISBN 978-0-292-76145-2 (library e-book)

ISBN 978-0-292-78879-4 (individual e-book) 
To Elena, my wife 
THIS PAGE INTENTIONALLY LEFT BLANK 